\title{
AIKAMME HYVEET KOROSTAVAT SOPEUTUMISTA TYÖELÄMÄÄN JA OMAA MENESTYMISTÄ
}

\author{
"Etiikka, politiikka ja kasvatus ovat tutkimukseni pääkäsitteitä. Väitän, \\ ettei niitä voi tarkastella toisistaan erillisinä, sillä ne ovat kietoutuneita \\ toisiinsa. Tutkimalla niiden välisiä yhteyksiä ja sisältöjä on mahdollista \\ löytää vastauksia onnellisuutta ja hyvää elämää koskeviin kysymyksiin, \\ jotka ovat kiehtoneet ihmisiä läpi vuosisatojen”, kirjoittaa Mervi Friman \\ väitöskirjastaan Ammatillisen asiantuntijan etiikka ammattikorkeakoulu- \\ tuksessa.
}

\section{MERVI FRIMAN}

$\mathrm{K}$ irjallisuudesta löytyy monia esimerkkejä siitä, kuinka onnea lähdetään etsimään erilaisten vaiheiden jälkeen päädytään lähtöpisteeseen. Tällainen esimerkki on Paulo Coelhon Alkemisti-teoksen andalusialainen paimen Santiago. Hän lähtee hakemaan aarretta, jonka avulla uskoo saavuttavansa ikuisen onnen. Pitkien matkojen, seikkailujen ja vaarojen, uusien ihmisten ja kokemusten jälkeen Santiago palaa kotiseudulleen. Hän havahtuu siihen, että aarre on juuri siellä kotitammen alla ja siellä se on koko ajan ollutkin. Santiago ymmärtää onnellisuuden olevan hänessä itsessään, hänen tavassaan elää, uskoa omiin unelmiinsa, löytää läheiset ihmiset ja olla osa heitä.

Tutkimukseni "Ammatillisen asiantuntijan etiikka ammattikorkeakoulutuksessa" lähtökohtainen moraalifilosofinen teoria on hyve-etiikka, joka tuo onnellisuuden, hyvän ja oikean mahdolliseksi jokaisessa hetkessä, päivässä, paikassa ja jokaisessa ihmisessä. Hyve-eettinen teoria lähtee käytännöllisestä elämästä ja palautuu siihen. Eettinen pohdiskelu koskettelee tuttuja todellisen elämän ilmiöitä, se on sovellettavissa käytäntöön.

Etiikasta puhutaan tänään monissa arkipäivän yhteyksissä. Kuluttajavalinnoissa banaanit voivat olla "eettisiä" tai Hennes\&Mauritzin oven ohittaminen voi tehdä ihmisestä eettisen. Yritysmaailmassa etiikasta on tullut kilpailuvaltti. Yrityk- set kertovat mielellään arvoistaan tai eettisistä koodeistaan. Yritykset tuntuvat jo silloin kilpailijoitaan paremmilta. Etiikka on näiden esimerkkien perusteella itsessään jo jotain hyvää ja oikeaa. Entä, kun Kimmo Sasi kertoo USA:n Irak-intervention yhteydessä amerikkalaisten ohjusten olevan eettisiä, kun ne surmaavat mahdollisimman vähän siviilejä?

Mistä etiikassa oikein on kysymys? Filosofiassa etiikka

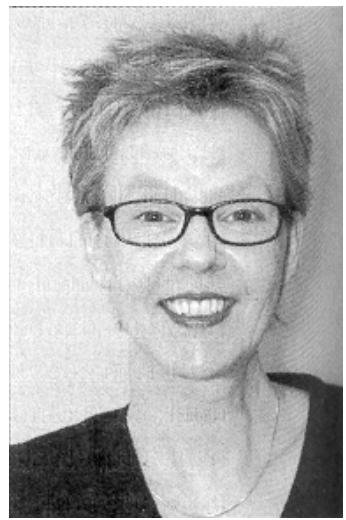

Mervi Friman on alue, jossa tutkitaan hyvän ja pahan, oikean ja väärän, arvojen ja normien maailmaa. Etiikan pääsuuntauksia on kolme, utilitaristinen etiikka, deontologinen etiikka ja hyveetiikka. Omassa tutkimuksessani lähtökohtani on hyve-etiikka. Hyve-etiikan juuret ovat antiikin ajan Kreikassa. Filosofi Aristoteleen teos Nikomakhoksen etiikka on hyve-etiikan perus-teos. Simo Knuuttilan suomentamana se ilmestyi vuonna 1989. Ajattelutapana hyve-etiikka on noussut keskeiseksi viimeisten kahdenkymmenen vuoden aikana. Suomalaisista filosofeista erityisesti Juha Sihvola on tarkastellut hyve-etiikkaa. Kansainvälisessä keskustelussa keskeisiä kommunitaristisen hyve-etiikan tutkijoita ovat Alisdair MacIntyre, Philippa Foot, Martha Nussbaum ja Charles Taylor. 
Hyve-etiikan traditiossa etiikka on yksinkertaisesti ihmisen tapa olla olemassa. Ihminen on itsessään oman etiikkansa ruumiillistuma eikä tiettyjen normien mukainen toimija, jolloin hänen hyvyytensä olisi mitattavissa ulkopuolelta asetettujen sääntöjen tottelemisena. Tässä kohdin hyve-etiikka poikkeaa ratkaisevasti deontologisesta ja utilitaristisesta etiikasta, joissa molemmissa korostuu universaali normittaminen ja normien noudattaminen. Hyve-etiikassa sen sijaan haetaan vastausta siihen, mitä on hyvä elämä ja kuinka se toteutuu.

Aristoteleen mukaan "olla onnellinen" tarkoittaa samaa kuin elää hyvin tai onnistua elämässä. Käsitykset elämän päämäärästä vaihtelevat, mutta Aristoteles uskoo niiden olevan jokseenkin samansuuntaisia kaikilla sivistyneillä ihmisillä. (EN, I, 4, 1095a, 18-23.) Sivistys puolestaan syntyy kasvatuksen kautta, sillä hyvin kasvatetulla ihmisellä on jo mielessään perusasiat hyvästä elämästä tai ainakin hän helposti omaksuu ne, kuten Aristoteles toteaa (EN I, 4, 1095b, 6-9). Ihmisen toiminnan päämäärä ei ole loppupiste tai jossakin vaiheessa saavutettava onnellisuuden tila, vaan pikemminkin koko elämän jatkuva toiminta itsensä kehittämiseksi. Päämäärä on joka hetki läsnä, sillä jokainen yksittäinen hyvä teko konstituoi hyvää elämää. Näin ollen ihmisen valmiudet toimia hyveellisesti ovat hyvän elämän välttämätön ehto. Hyveiden yhtäaikaisuus ja tasapainoisuus on tärkeää. Aristoteleen mukaan ihminen ei voi toteuttaa hyvää elämää olemalla vähemmän rohkea, mutta vastaavasti enemmän nautinnonhaluinen.

\section{JÄRKI, TIETO JA HYVÄ ELÄMÄ}

Miten voisi oppia elämään hyvin? Aristoteleen etiikassa järjellä, ihmisen erityisominaisuudelle, on keskeinen osa hyvässä elämässä. Ihmiselle ominainen tehtävä on sielun toiminta järjen mukaan tai toiminta, joka ei tapahdu ilman järjen ohjausta. (EN I, 7, 1098a, 1-10) Aristoteles korostaa, että ihminen on luonnostaan yhteisössä elävä olento (EN I, 7, 1097b, 10-11). Tällöin järjen tehtävänä on osoittaa sellaiset toiminnan tavat, jotka tekevät koko yhteisön elämän mahdollisimman hyväksi. Hyveellinen ihminen ei siis voi tyytyä vain oman itsensä onnellisen elämän raken-tamiseen, vaan hän näkee toisen onnellisuuden yhtä tärkeäksi ja osaksi omaa onneaan. Tämä yhteisössä eläminen, toinen toisensa huomioon- ottaminen, toisten puolesta toimiminen ja ihmisten toistensa tarvitsevuus on Aristoteleen kielellä politiikkaa. Näin tulkiten politiikka on siis kaukana puoluepolitiikasta. Politiikka on yksinkertaisesti elämistä yhdessä muiden kanssa ja yhteistä hyvää tuottaen.

Kasvatuksen ja kasvattajan tehtävänä antaa tietoa ja samalla osoittaa, mitkä ovat hyviä tekoja, toteuttaa niitä ja itse todistaa näin hyveellisyyden mielekkyys. MacIntyre (1981) käyttää tästä termiä ihmismielen kouliminen. Hyveellinen toiminta edellyttää järjen tuottamaa arvostelukykyä, sillä hyve-etiikka ei anna yksiselitteisiä normeja. Se haastaa ihmisen jatkuvaan oikean keskitien hakemiseen. (EN I, 3,1095a)

\section{AHNEUS, ANTELIAISUUS JA TUHLAAVAISUUS}

Aristoteleen selvitys anteliaisuudesta havainnollistaa hyveen keskitien problematiikkaa ja antaa samalla herkullisen kuvan hänen esitystavastaan. "Hyveelliset toiminnat ovat jaloja, ja ne tapahtuvat jalon päämäärän takia. Niinpä anteliaskin antaa asian jalouden takia ja oikein. Hän antaa niille, joille kuuluu antaa niin paljon kuin tulee antaa silloin, kun on oikein antaa ja muissakin suhteissa siten kuin oikeaan antamiseen kuuluu. Tämän hän tekee mielellään ja surutta. Sillä hyveellinen antaminen on miellyttävää ja tuskatonta - kaikkein vähiten se on antajalle kärsimys. (EN IV, 1, 1120a, 24-28) Anteliaisuus on suhteessa henkilön varalli-suuteen, sillä teon anteliaisuus ei riipu annetun määrästä, vaan antajan luonteesta; sen perusteella hän antaa omaisuuden sallimalla tavalla. Mikään ei estä, että vähemmän antava on anteliaampi, jos hänellä on vähemmän annettavaa. (EN IV, 1, 1120b, 7-9). Tuhlaavaisuus on liioittelua antamisessa ja siinä ettei ota, ja siihen kuuluu, että ottaa liian vähän; ahneuteen taas kuuluu, että antaa liian vähän ja ottaa liikaa paitsi ehkä pienten asioiden yhteydessä." (EN IV, 1121a, 13-16) Näin siis hyve, tässä tapauksessa anteliaisuus, tulee asetetuksi kahden ääripään, tuhlaavaisuuden ja ahneuden välille. Samalla tulee esiin se, että hyveellinen toiminta on aina suhteutettava tilanteeseen, kohteeseen, päämäärään ja antajaan itseensä.

Järki eli tieto hyvästä elämästä ei yksin riitä. Tarvitaan myös harjoitusta. Aristoteles kirjoittaa:

"Hyveet saamme niin, että olemme harjoitelleet niitä käytännössä, ja sama koskee myös kaik- 
kia taitoja. Asiat, jotka täytyy oppia tekemään, opitaan tekemällä niitä. Ihmisistä tulee rakentajia rakentamalla ja lyyran soittajia lyyraa soittamalla. Samoin tekemällä oikeudenmukaisia tekoja tulemme oikeudenmukaisiksi ja toimimalla kohtuullisesti tulemme kohtuullisiksi ja mie-huullisia tekoja tekemällä miehuullisiksi." (EN1103a3o-1103b, 1-4.)

\section{HYVEET JA ITSEKONTROLLI}

Hyveitä voisi siis luonnehtia harjoituksen myötä syntyväksi itsekontrolliksi. Kontrolli auttaa ihmistä kaikissa oloissa, niin tuskan ja pelon kuin nautinnonhalunkin edessä, säilyttämään harkintakykynsä ja saa hänet noudattamaan toiminnassaan intohimotonta arvostelukykyä sen suhteen, mikä on milloinkin oikea teko. Hyveellisen ihmisen täytyy itse ratkaista, missä polku arkisen elämän vaihtelevissa tapauksissa menee. Emotioille, luovuudelle, mielikuvitukselle ja tilanteeseen vaikuttavien seikkojen kuuntelemiselle jää tilaa. (Elenius 2003, 50-51.) Järki ei siten sulje pois tuntemista ja herkkyyttä, vaikka tällaisia epäilyjä on hyve-etiikkaa kohtaan esitettykin.

Onko tämä liian yksinkertaista puhetta globalisoituvassa, postmodernissa, teknologisten saavutusten ja innovaatioiden täyttämässä maailmassa? Vai tuntuvatko Aristoteleen ajatukset liian monimutkaisilta yksioikoiseen markkinatalouden laeilla toimivaan maailmaan, jossa ihmiset voivat löytää työelämässä paikkansa osina kansallista innovaatiojärjestelmää tai yksityiselämässä osina ylikansallista mcdonaldsoitumiskulttuuria? Tarvitseeko yhden ihmisen lainkaan pysähtyä miettimään omaa onnellisuuttaan tai onko ainakaan työelämän turbulenssissa elävillä edes aikaa moiseen pohdintaan? Tai miksi pohtia, jos tuntuu siltä, että vaikuttamismahdollisuudet omaa elämää koskeviin asioihin ovat olemattomat?

Miksi siis ylipäänsä puhua hyvästä tai oikeasta, miksi puhua tavallisen ihmisen mahdollisuuksista tehdä politiikkaa eli osallistua ja tuottaa yhtei-söllistä elämää? Perustelen asiaa globalisoi-tumisen tematiikasta.

Globalisoitumista pidetään ihmiskuntaa yhdistävänä prosessina. Ei ole kuitenkaan yksiselitteistä, onko se yhdistänyt ihmisiä ja kulttuureja vai onko se synnyttänyt tarpeen asettua puolustusasemiin. Samaan aikaan kuin tietotekniikka lähentää ja verkottaa kaukaiset ihmiset toisiinsa, voimistuvat uskonnolliset liikkeet ja pyrkimyk- set ymmärtää ja hyväksyä toiset kapeasti suhteessa omiin arvoihin, kulttuuriin ja ymmärrykseen. On käynnissä vuoropuhelu, jossa ihmiset hakevat paikkaansa juuriltaan samanaikaisesti kuin pyrkivät selviytymään juurettomuudessa.

Hyve-etiikan vastaus on yksinkertainen: ihmisillä on universaalisti perustavanlaatuisia samanlaisia kokemuksia, kuten syntymä, kuolema, nälkä, seksuaaliset halut, ilo tai suru (Nussbaum 1998). Nämä tekevät ihmisistä toistensa kaltaisia siten, että me kaikki myös perimmiltämme tarvitsemme ja haluamme samanlaisia asioita: rakkautta, ystävyyttä, rohkeutta, mutta myös mahdollisuuksia antaa rakkautta, jakaa ystävyyttä tai olla heikkoja. Samanlaisuus tuottaa ihmisiin myös toistensa tarvitsevuuden.

\section{YHTEISET KOKEMUKSET}

Ihmisten samanlaisuuden teema elää monin tavoin ajassamme, vaikka me, jotka näimme tuikitavallisena syyskuun iltapäivänä onlinena World Trade Centerin tornien sortumisen, menetimme epäilemättä ainakin hetkeksi uskomme ihmiskunnan yhteisten arvojen olemassaoloon. Hyve-etiikka perustuu kuitenkin ihmisten yhteisille eettisille kokemuksille. Mistä tälle löytyisi perusteluja? Vastauksia löytyy psykologiasta ja sosiologiasta, mutta käytän tässä esimerkkinä kahta muuta lähdettä.

Uskontofilosofi Mircae Eliade (1993) on vakuuttanut ihmiskunnan yhteisyyttä erilaisten rituaalien merkitsemänä. Eliaden mukaan maailman jokaisessa kolkassa merkittäviä juhlan aiheita ovat uuden alkaminen, vanhan päättyminen, puhdistautuminen, pahan karkottaminen ja yhteisöön liittyminen. Nämä ihmisille yhteiset kokemukset näkyvät vuoden alkamisen, hautajaisten tai häiden juhlinnassa. Vaikka juhlien muodot vaihtelevat karnevaaleista hillitympiin pohjoismaisiin tilaisuuksiin, ovat sisällöt ja merkitykset niihin osallistuville samoja.

\section{POSTMODERNIN ARVOT}

Globalisoitumisen aikaan on liitetty postmodernin käsite. Postmoderni korostaa yhteisten arvojen katoamista, lineaarisen aikakäsityksen murtumista ja yksilön fragmentoitumista. Näin on vastattu ylivoimaiseksi käyvälle kokonaisuuksien hallitsemiselle ja ihmisille yhteisten päämäärien hahmottamiselle. Postmodernissa identiteettidiskurssissa ihmisen itseys on nähty jatkuvana 
pro-sessina, jonka sen raskaus on puettu muun muassa identiteetin luomisen juhlan kaapuun, kuten mm. Hall (1999) tekee. Joka aamu voimme siis nousta yhtä epävalmiina ja avoimena kaikkeen mahdolliseen vastaan tulevaan. Kun sitten päivän aikana juhlimme perheen kanssa, työyhteisössä tai harrastusten parissa, luomme kuhunkin tilanteeseen sopivan identiteetin arvoineen ja asenteineen, ulkoisine ja sisäisine merkkeineen.

Työelämässä globalisoituminen konkretisoituu ylikansallisten yritysten toimintana, jolloin taloudellinen tuottavuus ja tehokkuus määrittävät toiminnan muodot ja tavoitteet kansallisvaltioiden rajoista piittaamatta. Ammatilliset kulttuurit ja ammattikuntainen yhtenäisyys hajoaa, kun yhtenä joukkona toteutetaan yrityksen arvoja, missiota, credoa ja strategioita. Ollila (2003) kuitenkin epäilee, että työelämän arjessa vallitsevia arvoja ovat pikemminkin ahneus, kateus ja omanedun tavoittelu. Tosin nämä eivät ole kaikille sallittuja ja jaettuja arvoja. Filippiiniläinen siivoja ei saa olla ahne, kun sen sijaan yksikön johtajalle ahneus on hyve.

Kasvatuksen tehtävä on kautta aikojen ollut vahvistaa ihmisen identiteettiä, sosiaalistaa yhteisöön sekä ohjata hyvään ja oikeaan. Miten tämä on mahdollista postmodernissa ajassa? Kasvatuksen tavoitteiden painotukset ovat historiallisissa vaiheissa ja kulttuurisissa konteksteissa vaihdelleet. Nykypäivän kasvatuskeskustelun jännitteet ovat monikulttuurisuuden, suomalaisen ja eurokansalaisuuden välillä.

Mikä tässä on koulun tehtävä? Pursiainen (2002) peräänkuuluttaa koulua totuusyhteisönä, jossa kriittisyys ja kasvaminen toteutuvat turvallisessa ympäristössä valtapolitiikkaa kyseenalaistaen ja uusia parempia mahdollisuuksia luoden. Mutta puhutaanko koulun ja kasvatuksen yhteydessä enää hyvästä vai onko arvopluralismi sama kuin arvottomuus? Hyvän määrittely ei ole syrjässä koulutuspolitiikassa. Se on läsnä, vaikkakin eri käsitteistöllä. Hyvään tartutaan yritysmaailmasta omaksutulla laadun ja arvioinnin sanastolla. Moninaiset Quality Management -ohjelmat tuottavat laatujärjestelmiä, joissa kerrotaan oppilaitosten oikeista ja tavoiteltavista toimintaproseduureista. Arvioitsijat kiertävät keräämässä tietoa toimintatavoista ja palkitsevat voittajat hyvistä käytänteistä.

Tutkimukseni on osaltaan valottaa etiikan, politiikan ja kasvatuksen yhteenpunoutu-mista tämän päivän Suomessa. Hyve-etiikka käytännös- sä toteutuvana politiikkana, nimenomaan järjen ohjaamana, sopii hyvin perspektiiviksi ammattikorkeakoulutuksen maailmaan, jossa teorian ja käytännön vuoropuhelu on keskeinen ontologinen, epistemologinen ja pedagoginen sitoumus.

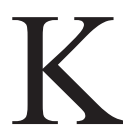

un ammattikorkeakoulut 1990-luvun alussa perustettiin, taustalla oli työelämän kehittämisen, kansainvälistymisen, laaja-alaisen osaamisen ja sivistystason kohottamisen odotuksia. Asiantuntijuudella nähtiin vastattavan työelämän muuttuviin tarpeisiin. Kun tutkimuksen viitekehyksenä on hyve-etiikka, olen jäsentänyt hyveiden tarkastelun kolmeen tasoon. Sisimmällä kehällä on ammatillinen asiantuntija itse, tässä tapauksessa siis ammattikorkeakoulusta valmistuva opiskelija. Toisella kehällä on työ, jota tarkastelen sekä työtehtävien suorittamisena että sosiaalisena työyhteisönä. Kolmannella kehällä on yhteinen maailmamme globaalina yhteisönä.

Hyve-etiikassa järjellä on keskeinen rooli luonteenhyveitä jalostavana tekijänä. On siis kysyttävä, mitä tuo järki on ammattikorkeakoulutuksessa on. Miten se avaa maailman opiskelijoille siten, että yksilöllisyys ja yhteisöllisyys ja toisaalta keskitiet löytyisivät? Miten sen myötä syntyvät sellaiset tavat, joita oppimalla tullaan hyviksi ammatti-alan asiantuntijoiksi?

Kun ammatilliset asiantuntijat sijoittuvat osaksi työelämää, jossa aina on kysymys taloudellisesti tehokkaasta ja tuottavasta toiminnasta, on syytä kysyä, tavoittaako hyve-etiikka tällaisen toiminnan, antaako se jäsennyksiä hyveellisyydelle talouselämässä. Otan esimerkiksi tuoreen Jyväskylän seudun työelämää koskevan uutisen. Eräällä tehtaalla otetaan käyttöön kuusi robottia ja samalla jää 75 ihmistä työttömäksi. Muutama saadaan eläkeputkeen, pari voidaan ehkä kouluttaa robottien hoitajiksi. Oliko tämä työelämän kehittymistä? Voiko taloudellinen toimija ylipäänsä olla hyveellinen? Sihvola (2003, 28-29) toteaa tästä sen, että Aristoteles kysyisi pikemminkin, voiko hyveellinen ihminen tavoitella voittoa. Sihvolan tulkinta on, että Aristoteleen vastaus on kielteinen. Siitä seuraa, että taloudellisen toimijan ei myöskään kannata olla hyveellinen, jos tavoitteena on voitto. Sihvola arvelee Aristoteleen vastaavan tähän, että hyveellisyydestä ei pidä luopua, vaan on hylättävä voiton tavoittelu. Tämä johtaa siihen, että hyveellinen elämä on normi, jonka perusteella on muokattava hyödyketuotannon periaatteita eikä päinvastoin. Olisiko tämä 
perustava haaste ammattikorkeakoulujen eettisten tavoitteiden pohdinnalle? Priorisoiko opetusta, tutkimusta ja kehittämistä voittoa tavoitteleva yritysten hyödyketuotanto vai hyveellisen elämän mahdollisuus, jolloin haluttaisiin koulutuksen keinoin vaikuttaa hyödyketuotannon suuntaan?

Tutkimukseni perspektiivi on ihmisessä, valmistuvassa opiskelijassa, tulevassa ammatillisessa asiantuntijassa. Olen hakenut vastausta ammatillisen asiantuntijan hyveellisyyteen kahdesta erilaisesta aineistosta. Niin sanottuja normatiivisia tekstejä edustavat kolme ammattikorkeakoulutusreformin alkuvuosina kirjoitettua teosta, joita ovat Jorma Ekolan Johdatus ammattikorkeakoulupedagogiikkaan (1992), Osmo Lampisen Ammattikorkeakoulut - vaihtoehto yliopistolle (1995) sekä Seppo Helakorven ja Anita Olki-nuoran Asiantuntijuutta oppimassa. Toinen osio koostuu opiskelijahaastatteluista. Ne olen kerännyt vuonna 2000 viideltätoista Hämeen ammattikorkeakoulun valmistumisvaiheessa ole-valta opiskelijalta. He edustivat tekniikan ja lii-kenteen, luonnonvarain ja kulttuurin koulutusaloja.

Lähestyin tekstejä dekonstruoivalla lukutavalla. Tällöin keskeistä oli se, että pyrin löytämään teksteistä myös sellaista, mitä niissä ei sanota ja kysymään, mitä-kysymyksen lisäksi myös miten ja missä rajoissa. Tekstianalyysin perusteella konstruoin molemmista tekstijoukoista ammatillisen asiantuntijan hyveprofiilit. Profiilit poikkeavat toisistaan. Normatiivisten tekstien hyveet korostavat työelämän odotuksiin sopeutumista, itseisarvoista muutosta, irrallisuutta sekä ihmisen jatkuvaa muuttuvaisuutta ympäristön vaatimuksia vastaavaksi. Opiskelijahaastattelujen perusteelta konstruoidut hyveet painottuvat omaan pärjäämiseen, yhteisöllisyyden tavoitteluun sekä itseksi tulemiseen. Siinä missä normatiiviset tekstit ilmensivät kasvatuksen ohjaavaa luonnetta, kaipasivat opiskelijat opettajia inhimillisen kohtaamisen osapuolina.

Kun hyveprofiileita tarkastelee hyve-etiikan päämääräisyyttä, yhteisöllisyyttä ja keskivälin periaatetta vasten, ei kumpikaan hyveprofiili täytä näitä edellytyksiä. Työ jää aktiviteetiksi, Aristoteleen mukaan poiesikseksi, jolla ei ole päämäärää. Työ praxiksena, jossa olisi sisäänrakennettuna arvokas päämäärä, ei näytä toteutuvan. Onko siis kasvatukselle ominainen hyvän intentionaalisuus väistynyt tai onko se annettu ammattikorkeakouluissa markkinoiden määriteltäväksi?

\section{LÄHTEET}

Aristoteles. Nikomakhoksen etiikka. Suomennos ja selitykset Simo Knuuttila (1981). (Ethica Nicomachea.) Gaudeamus. (Tekstissä EN.)

Coelho, P. (2002). Alkemisti. Suom. Sanna Pernu. (O Alquimista). Bazar. Otava.

Ekola, J. (toim.1992). Johdatus ammattikorkeakoulupedagogiikkaan. WSOY.

Elenius. J. (2003). Hyveen maantiede. Teoksessa I. Haavisto (toim.) Hyve ja markkinatalous. EVA-raportti 15.9.2003. Taloustieto. Yliopistopaino, 47-54.

Eliade, M. (1993). Ikuisen paluun myytti : kosmos ja historia. Suom. T. Laitila. (Le mythe de l'éternel retour.) Loki-kirjat. Karisto.

Hall, S. (1999). Identiteetti. Suom. ja toim. M. Lehtonen \& J. Herkman. (Identity.) Vastapaino.

Helakorpi, S. \& Olkinuora, A.(1997). Asiantuntijuutta oppimassa. WSOY.

Lampinen, O. (toim.1995). Ammattikorkeakoulut - vaihtoehto yliopistolle. Gaudeamus.

Nussbaum, M. C. (1998). Cultivating Humanity. A Classical Defense of Reform in Liberal Education. London: Harvard University Press.

Ollila, M-R. (2003). Ahneus ja kateus - hyveitä vai paheita. Teoksessa I. Haavisto (toim.) Hyve ja markkinatalous. EVA-raportti 15.9.2003.

Taloustieto. Yliopistopaino, 95-106.

Pursiainen, T. (2002). Ammattien etiikka. Teoksessa R. Sarras (toim.) Etiikka koulun arjessa. Otava, 35-54.

Sihvola, J. (1998). Toivon vuosituhat. Eurooppalainen ihmiskuva ja suomalaisen yhteiskunnan tulevaisuus. Sitran julkaisusarja 185. Atena. Sihvola, J. (2003). Miksi talous jäi filosofian sokeaksi pisteeksi? Teoksessa I. Haavisto (toim.) Hyve ja markkinatalous. EVA-raportti 15.9.2003. Taloustieto. Yliopistopaino, 19-30.

Mervi Friman väitteli Jyväskylän yliopiston kasvastustieteellisessä tiedekkunnassa 10. maaliskuuta vastaväittäjänä dosentti Leena Ahteenmäki-Pelkonen ja kustoksena professori Anja Heikkinen. 